\title{
Zooplankton richness in farm ponds of Andalusia (southern Spain). A comparison with natural wetlands
}

\author{
David León ${ }^{1, *}$, Patricio Peñalver ${ }^{1}$, Jesús Casas $^{2}$, Melchor Juan², Francisca Fuentes ${ }^{2}$, Irene \\ Gallego $^{2}$ and Julia Toja ${ }^{1}$ \\ ${ }^{1}$ Department of Ecology and Plant Biology. University of Seville. Reina Mercedes Avenue, s/n cp 41012. Seville. \\ Spain. \\ ${ }^{2}$ Department of Plant Biology and Ecology. University of Almeria. 04120-Almeria. Spain. \\ * Corresponding author: leonmuez@us.es
}

Received: 15/11/08

Accepted: 26/7/09

\begin{abstract}
Zooplankton richness in farm ponds of Andalusia (southern Spain). A comparison with natural wetlands

This study shows the results of an extensive survey carried out in spring 2007 on 120 farm ponds in Andalusia (South of Spain). Pond use was diverse, but the most common uses were irrigation of vast areas of land and livestock watering. Zooplankton showed an unexpected richness in these previously unstudied water bodies which lie on private properties. A total of 103 taxa were identified (62 rotifera, 27 cladocera, 8 copepoda and 6 ostracoda). When results are compared with an extensive survey carried out at the same time in the protected wetlands of Andalusia, we found that there are many species exclusive to both the farm ponds and the protected wetlands. This suggests high complementary between artificial and natural aquatic habitats, which highlight the role of farm ponds in biodiversity conservation. Furthermore, our results showed that farm ponds with natural substrate have a higher diversity and species richness of zooplankton than those with artificial substrate. Farm ponds and other farming-related ecosystems are becoming important in both ecological and management studies, because they are increasing in landscapes all over the world. This study is part of a wider project to investigate the environmental improvement of small artificial water bodies in Andalusia and results will be used to promote a more useful management policy for existing and future farm ponds in this region.
\end{abstract}

Key words: Farm ponds, zooplankton, management, substrate, landscape.

\section{RESUMEN}

Riqueza del zooplancton en balsas de riego de Andalucía (sur de España). Comparación con humedales naturales

Se presentan resultados de un muestreo extensivo de 120 balsas de riego llevado a cabo en la primavera de 2007 en Andalucía (Sur de España). Los datos de zooplancton revelan una inesperada riqueza de especies en estos cuerpos de agua, que no habian sido estudiados hasta la actualidad, porque muchos de ellos son de reciente creación y están en propiedad privada. Su uso es variado, utilizándose principalmente para el riego de vastas áreas y como abrevaderos de ganado. Se han identificado un total de 103 taxa (62 rotíferos, 27 cladóceros, 8 copépodos y 6 ostrácodos). Cuando los resultados se compararon con un muestreo extensivo llevado a cabo en el mismo periodo en humedales naturales protegidos de Andalucía, se encontraron taxones exclusivos tanto en las balsas como en los humedales, sugiriendo que estos nuevos sistemas podrían ser reservorios para la biodiversidad en todo tipo de paisajes agrícolas. Por otra parte, los resultados evidencian que las balsas con sustrato natural tienen una mayor diversidad y riqueza de especies de zooplancton que las balsas con sustrato artificial. Las balsas de riego y otros ecosistemas asociados a ambientes agrícolas están adquiriendo importancia en ecología y estudios de gestión, ya que están proliferando en los paisajes de todo el mundo. Este estudio es parte de un proyecto de mayor envergadura acerca de la capacidad ambiental de las balsas de riego de Andalucía. Estos resultados se usarán para promover una política de gestión más adecuada en futuras balsas de riego de la región.

Palabras clave: Balsas de riego, zooplancton, gestión, sustrato, paisaje. 


\section{INTRODUCTION}

Ponds and other wetlands have been historically desiccated or drained in Europe and all over the world. Estimates of nearly $70 \%$ have been recorded in some countries (Antón-Pardo et al., 2008; Céréghino et al., 2008; Lougheed \& ChowFraiser, 2002; Oertli et al., 2002; Oertli et al., 2005; Robson \& Clay, 2005; Scher et al., 2004). Since the 1970s, researchers and practitioners have been trying to reach a consensus on how to protect wetlands and several Conventions and Directives (RAMSAR, Habitat Directive, Water Framework Directive) have been considered. However, the loss of biodiversity in these systems still continues. One of the causes for this continuing degradation is the demand of water for agriculture. However, the requirement for water, principally in the semiarid regions of the Iberian Peninsula, has given rise to an increase in the number of farm ponds associated with new irrigated land (Williams et al., 2008). As such, it is possible that these new landscape features could significantly contribute to enhancing biodiversity in farming areas and their surroundings. Furthermore, aquatic systems in agricultural landscapes are starting to be acknowledged as "pockets" of biodiversity (Céréghino et al., 2008; Davies et al., 2008), and we believe that farm ponds are a suitable source of investigation for colonization rates, cumulative richness and trophic relationships in addition to other more traditional areas, such as the Doñana wetlands, which has been studied for decades (Marín Cabrera \& García Novo, 2005; Serrano et al., 2006).

Few studies relating to the diversity in aquatic systems in farmed landscapes have been undertaken although there is some evidence to suggest that the interest of the research community has been stimulated (Davies et al., 2008; Denoël \& Ficetola, 2008; Hoffman \& Dodson, 2005; Robson \& Clay, 2005; Williams, 1997; Williams et al., 2003; Mittelbach et al., 2001). In all cases, these researchers conclude that ponds have high species richness and, accordingly, should be taken into account for strategies of management and conservation in those regions where they occur.
Andalusia (south of Spain) has a close relationship with agriculture, and a large number of farm ponds have been created in the last few years (CMA, 2007). A recent inventory by remote sensing and aerial images has identified a total of 16543 ponds (Agencia Andaluza del Agua, 2006), and any of these have been subjected to a limnological or faunal survey (with the exception of birds surveys). The aim of this study is to investigate the zooplankton diversity of farm ponds in Andalusia, and to detect if there is any pattern of distribution, requirement of management or construction strategies in these areas to preserve biodiversity. Furthermore, a comparison is made between farm ponds and the protected natural wetlands of Andalusia to test the hypothesis that natural farm ponds are important for biodiversity conservation in the agricultural landscape. Finally, in contrast to other studies of aquatic systems of Andalusia (Alonso, 1998; Furest \& Toja, 1987; Junta de Andalucía, 2002 and 2005; Serrano et al., 2006), nothing is known about the zooplankton community in farm ponds. This study is part of a wider research program focussing upon the environmental improvement of small artificial water bodies in Andalusia.

\section{STUDY AREA}

Andalusia (south of Spain), has an area of about 8.8 million hectares, and is located in the south of Europe (Fig. 1). This geographic situation between two continents and two marine areas (Mediterranean Sea and Atlantic Ocean) creates special climatic conditions, and offers an interesting opportunity to study biogeography and other processes of species distribution, as other authors have done (Alonso, 1987; Miracle, 1982). The percentage of steppe, for example, covers approximately $10 \%$ of the territory, and its crustacean diversity is more similar to Morocco and other North-African countries than to the rest of Spain and Europe (Alonso, 1987; Ramdani, 1988). In addition to steppe landscapes, calcareous mountain ranges occur in the south east of the region and siliceous mountain ranges can be found in the north-west with the Valley of Gua- 


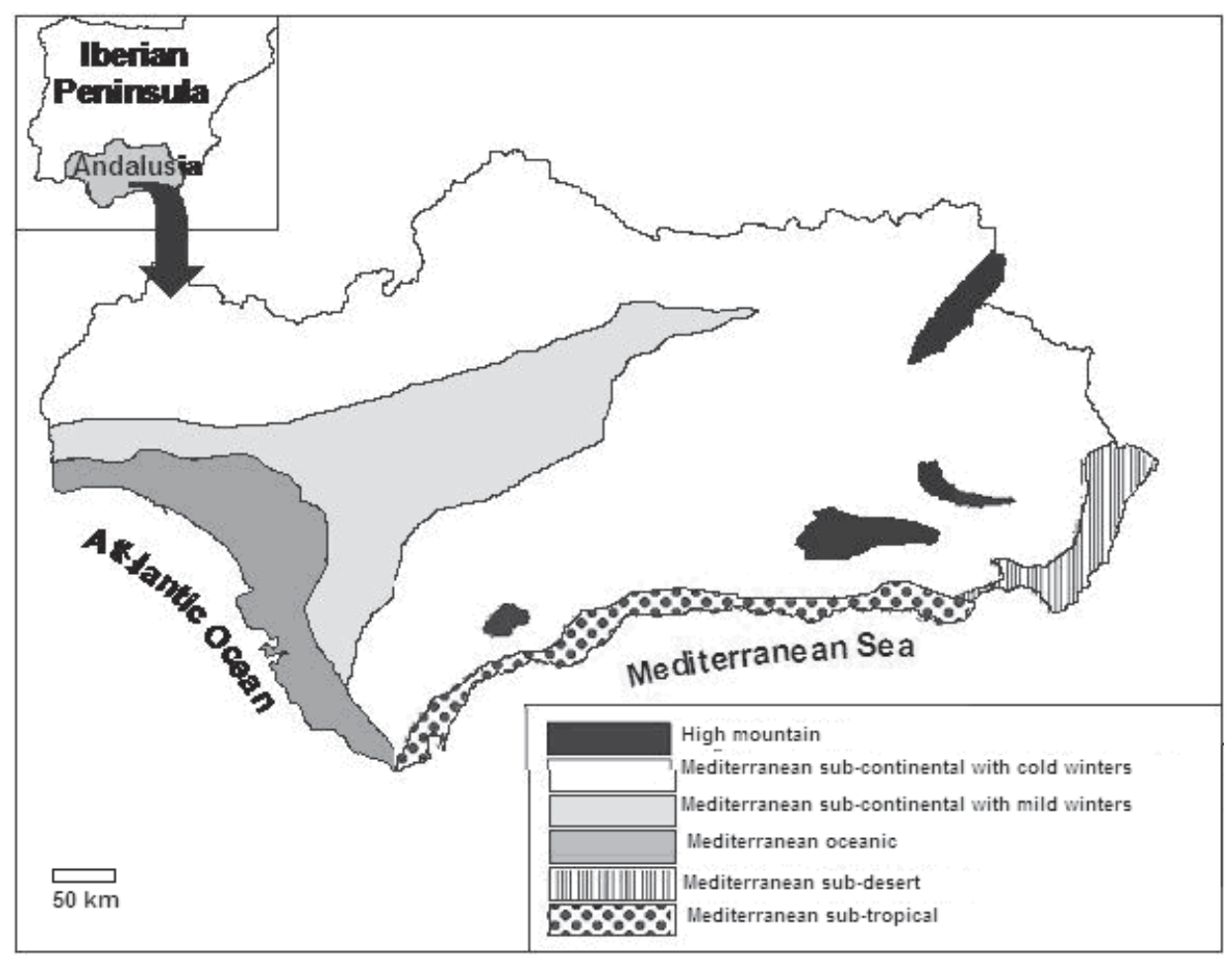

Figure 1. Geographical location and main climatic areas of Andalusia. Localización geográfica y principales áreas climáticas de Andalucía.

dalquivir River acting as an axis of separation between them. Although the Mediterranean climate regime is paramount, there are significant climatic variations which contribute to a considerable diversity of farming systems. Farm ponds, in fact, have been created to support different farming land uses in Andalusia; olive crops are found in the heart of the region; the 'dehesa' system, which is a typical Spanish landscape with Quercus ilex, Quercus suber and scrub associated with extensive cattle or pig ranching is found in the northern mountains and valleys; citrus fruits and early season strawberries are grown in the south west; subtropical fruits in the south, and protected greenhouse horticulture is common place in the east.

\section{MATERIALS AND METHODS}

Andalusia covers an area of about $90000 \mathrm{~km}^{2}$. Leibold (1999) and Dodson et al. (2000) argue that this is a suitable scale to study pond land- scapes (in Mittelbach et al., 2001). An extensive survey was carried out in spring 2007, after a selection of a representative number of farm ponds in the whole study area (Fig. 2). The previous selection by aerial images and photo-interpretation was performed by EGMASA. This study revealed a total of 16543 farm ponds. 120 of these were selected as a representative sub-sample for the different geographical and land use areas (Fig. 2), and the survey was carried out by the Universities of Seville, Granada and Almeria, to cover all the areas at once. This survey matched up with the "Andalusia Wetlands Project", an extensive monitoring campaign of over 60 natural wetlands, which was carried out by the "Consejeria de Medio Ambiente" through EGMASA. Therefore samples could be compared on a temporal and a spatial scale. As the monitoring and identification followed the recommendations of our group, confidence about the results was high.

Pond categories were assigned as follows: RUN, natural runoff farm pond created by damming off 


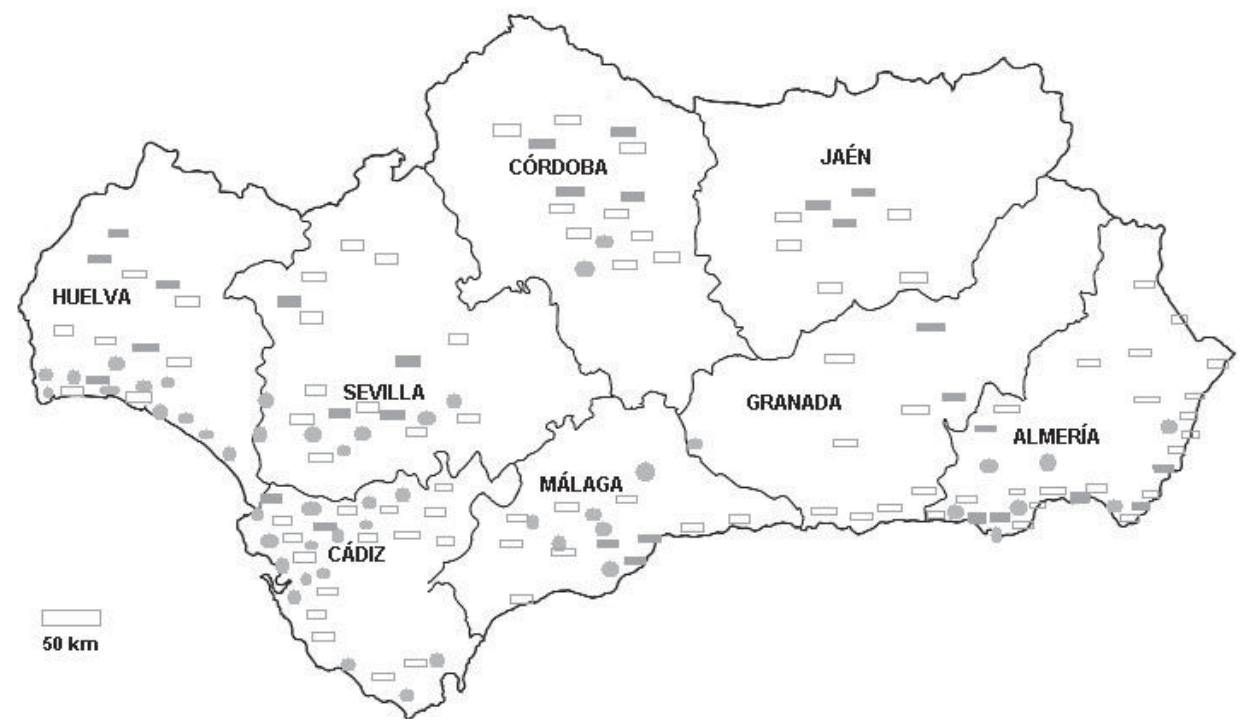

Figure 2. Approximate distribution of farm ponds and wetlands by administrative provinces compared in this study. Circles represent wetlands, rectangles represent farm ponds, and those shaded are the sampled ones for the present study. Distribución aproximada de las balsas de riego y los humedales según provincias. Los círculos representan los humedales, los rectángulos las balsas y los coloreados aquellos que se seleccionaron para el estudio intensivo.

a temporary stream; EXC, excavated farm pond with natural substrate; WET, natural wetlands of the Andalusia Wetlands Project; PLA, excavated or elevated farm pond lined with plastic; CON, excavated farm pond made of concrete. Percentage of submerged and emergent macrophytes was estimated and other characteristics were measured and identified in situ (total area of the pond, maximum depth, land use, water origin).

As most of the farm ponds were on private land (115 of 120), a concerted effort was made to understand the pond management decisions of each farmer. Pond owners were intervied in situ at the beginning of the survey (as Robson \& Clay, 2005 did). This was a vital part of the exercise since: the farmers are who use the farm ponds, so they should know what the project was about. Furthermore, as one of the main objectives of the project was to develop a pond management handbook with the aim of enhance biodiversity conservation, it was important to keep these vital stakeholders fully informed.

Physico-chemical and biological samples were taken from every farm pond in the same way to avoid sampling differences. Each farm pond was divided into four or six sections depending of the size of the water body (smaller or bigger than $10000 \mathrm{~m}^{2}$ respectively). Thereafter we select at random two or three sections (according to size) of the pond to make the survey. Finally, "centre" and "shore" sampling points were taken into account in every selected section. In this way, the majority of habitats are sampled. Conductivity, $\mathrm{pH}$ and oxygen concentration were measured in situ. 10 litres as a whole were filtered through a $40 \mu \mathrm{m}$ net and the filter was preserved in $4 \%$ formaldehyde solution for the zooplankton quantitative record. Volume from each selected site was equalised, and sampling was made with a $6 \mathrm{~cm}$ diameter tube in order to integrate the whole water column in every case. A zooplankton qualitative sub-sample consistent in various horizontal hauls with a $35 \mu \mathrm{m}$ net was made. Most of the taxa were identified to species level, in contrast to similar studies where genus was the limit of identification (Lougheed \& Chow-Fraser, 2002). Water chemistry (Table 1 and 2) was analysed by the laboratory of Junta de Andalucía.

The Jaccard's coefficient of similarity (the ratio between the number of common taxa and total number of taxa) was used to quantify the similarity between paired community compositions. Pearson 
Table 1. Values (average, maximum and minimum) for different limnological variables of studied farm ponds. First row indicates provinces (see Figure 2) where farm ponds were surveyed. They are arranged according to west-east axis. Valores (medio, máximo y mínimo) para diferentes variables limnológicas en las balsas de riego estudiadas. La primera fila indica las provincias (Figura 2) donde se muestrearon. Están ordenadas según el eje oeste-este.

\begin{tabular}{|c|c|c|c|c|c|c|c|c|}
\hline & HU & CA & SE & $\mathrm{CO}$ & JA & MA & GR & $\mathbf{A L}$ \\
\hline$\overline{\mathrm{pH}}$ & $\begin{array}{c}8.12 \\
(11-3)\end{array}$ & $\begin{array}{l}8.36 \\
(9-7)\end{array}$ & $\begin{array}{c}8.51 \\
(10-7)\end{array}$ & $\begin{array}{c}8.62 \\
(10-7)\end{array}$ & $\begin{array}{l}8.38 \\
(9-8)\end{array}$ & $\begin{array}{l}8.36 \\
(9-8)\end{array}$ & $\begin{array}{c}9.03 \\
(10-8)\end{array}$ & $\begin{array}{c}8.45 \\
(10-8)\end{array}$ \\
\hline $\begin{array}{l}\mathrm{HCO}_{3}^{-} \\
(\mathrm{meq} / \mathrm{l})\end{array}$ & $\begin{array}{c}1.14 \\
(4.56-.01)\end{array}$ & $\begin{array}{c}1.02 \\
(2.24-.38)\end{array}$ & $\begin{array}{c}1.12 \\
(3.34-.25)\end{array}$ & $\begin{array}{c}1.52 \\
(3.28-.25)\end{array}$ & $\begin{array}{c}3.25 \\
(6.07-.52)\end{array}$ & $\begin{array}{c}2.77 \\
(4.7-.25)\end{array}$ & $\begin{array}{c}2.29 \\
(5.25-.62)\end{array}$ & $\begin{array}{c}3.01 \\
(4,7-.25)\end{array}$ \\
\hline $\begin{array}{l}\mathrm{C} \\
(\mathrm{mS} / \mathrm{cm})\end{array}$ & $\begin{array}{c}.71 \\
(3.26-.18)\end{array}$ & $\begin{array}{c}3.44 \\
(9.65-.26)\end{array}$ & $\begin{array}{c}1.96 \\
(7.60-.08)\end{array}$ & $\begin{array}{c}.87 \\
(3-.11)\end{array}$ & $\begin{array}{c}5.66 \\
(24-.42)\end{array}$ & $\begin{array}{c}1.95 \\
(4.92-.25)\end{array}$ & $\begin{array}{c}.74 \\
(1.03-.56)\end{array}$ & $\begin{array}{c}1.39 \\
(2.46-.23)\end{array}$ \\
\hline $\begin{array}{l}\text { SS } \\
(\mathrm{mg} / \mathrm{l})\end{array}$ & $\begin{array}{c}1079.99 \\
(4562.38- \\
105.3)\end{array}$ & $\begin{array}{c}1254.71 \\
(3468.33- \\
136.44)\end{array}$ & $\begin{array}{c}1076.6 \\
(2958.89- \\
47.95)\end{array}$ & $\begin{array}{c}503.78 \\
(1558.64- \\
55.01)\end{array}$ & $\begin{array}{l}1791.14 \\
(4403.6- \\
385.65)\end{array}$ & $\begin{array}{c}1253.77 \\
(3075.77- \\
153.18)\end{array}$ & $\begin{array}{c}544.97 \\
(827.22- \\
347.58)\end{array}$ & $\begin{array}{c}1394.44 \\
(4658.73- \\
116.77)\end{array}$ \\
\hline $\begin{array}{l}\text { Ammonia } \\
(\mu \mathrm{M})\end{array}$ & $\begin{array}{c}15.42 \\
(96.88-.29)\end{array}$ & $\begin{array}{c}25.77 \\
(154.88-.29)\end{array}$ & $\begin{array}{c}12.3 \\
(57.65-.29)\end{array}$ & $\begin{array}{c}12.51 \\
(48.47-.01)\end{array}$ & $\begin{array}{c}70.39 \\
(327.59-4.59)\end{array}$ & $\begin{array}{c}23.34 \\
(150.59-1.76)\end{array}$ & $\begin{array}{c}8.14 \\
(26.82-.29)\end{array}$ & $\begin{array}{c}13.57 \\
(105.65-1.06)\end{array}$ \\
\hline $\begin{array}{l}\text { Phosphate } \\
(\mu \mathrm{M})\end{array}$ & $\begin{array}{c}2.75 \\
(14.19-.48)\end{array}$ & $\begin{array}{c}1.76 \\
(9.71-.45)\end{array}$ & $\begin{array}{c}2.39 \\
(16.19-.01)\end{array}$ & $\begin{array}{c}7.58 \\
(34.48-.29)\end{array}$ & $\begin{array}{c}1.39 \\
(3.26-.52)\end{array}$ & $\begin{array}{c}4.76 \\
(29.03-.01)\end{array}$ & $\begin{array}{c}12.35 \\
(25.9-.48)\end{array}$ & $\begin{array}{c}12.26 \\
(77.52-.52)\end{array}$ \\
\hline $\begin{array}{l}\text { Tphosphorous } \\
(\mu \mathrm{M})\end{array}$ & $\begin{array}{c}6.3 \\
(29.97-1.58)\end{array}$ & $\begin{array}{c}4.1 \\
(14.97-1.45)\end{array}$ & $\begin{array}{c}12.18 \\
(78.23-1.29)\end{array}$ & $\begin{array}{c}17.2 \\
(59.39-.87)\end{array}$ & $\begin{array}{c}3.02 \\
(5.52-1.55)\end{array}$ & $\begin{array}{c}5.33 \\
(25.32-1.45)\end{array}$ & $\begin{array}{c}19.53 \\
(49.97-1.94)\end{array}$ & $\begin{array}{c}24.29 \\
(113.81-1.55)\end{array}$ \\
\hline $\begin{array}{l}\text { Chla } \\
(\mu \mathrm{g} / \mathrm{l})\end{array}$ & $\begin{array}{c}40.87 \\
(367.31-.93)\end{array}$ & $\begin{array}{c}60.91 \\
(352.6-.05)\end{array}$ & $\begin{array}{c}26.43 \\
(89.2-1.5)\end{array}$ & $\begin{array}{c}54.77 \\
(156.46-2.76)\end{array}$ & $\begin{array}{c}5.45 \\
(14.78-.81)\end{array}$ & $\begin{array}{c}6.32 \\
(21.40-.8)\end{array}$ & $\begin{array}{c}37.4 \\
(94.6-1.6)\end{array}$ & $\begin{array}{c}72.86 \\
(489.2-.1)\end{array}$ \\
\hline$n$ & 11 & 9 & 17 & 13 & 9 & 8 & 4 & 11 \\
\hline
\end{tabular}

coefficient was used for correlations between the total number of zooplankton taxa (cumulative richness) and pond size, with software SPSS 11. PRIMER version 5 was used to test similarities on taxa composition between samples (MDS and ANOSIM), as for analysis of Principal Components in water quality. Diversity values are referred to Shannon index $\left(H^{\prime}\right)$.

\section{RESULTS}

A total of 120 farm ponds were visited during spring 2007 across Andalusia (Fig. 2). Climatic variety is high in the area and the origin of water and management of each pond is different by regions; a summary of mainly chemical factors analysed is shown in Table 1 to contrast the main characteristics between regions. The results are only related to 90 farm ponds. The remaining 30 ponds were selected in the field and as a result, water chemistry was not analysed. However, these ponds are close to the 11 Almeria farm ponds included in the analysis (Fig. 2, Table 1)
Table 2. PCA analyses showing three first axis explaining main variance of data. First axis is related to salinity, meanwhile second and third are associated with trophic level (chlorophyll-total organic carbon and phosphorous). Análisis PCA mostrando los tres ejes que explican más varianza de los datos. El primero se refiere a la salinidad, mientras que el segundo y el tercero están asociados al grado de eutrofia (clorofila-carbono orgánico total y fósforo).

\begin{tabular}{lrrr}
\hline Variable & \multicolumn{1}{c}{ PC1 } & \multicolumn{1}{c}{ PC2 } & \multicolumn{1}{c}{ PC3 } \\
\hline pH & 0.005 & 0.265 & 0.044 \\
Alkalinity & 0.118 & 0.040 & 0.034 \\
Chloride & $\mathbf{0 . 3 6 4}$ & 0.093 & -0.008 \\
Sulphate & $\mathbf{0 . 3 4 1}$ & -0.159 & 0.008 \\
Calcium & $\mathbf{0 . 3 5 8}$ & -0.131 & 0.103 \\
Magnesium & $\mathbf{0 . 3 5 3}$ & -0.124 & 0.103 \\
Sodium & $\mathbf{0 . 3 5 3}$ & 0.114 & 0.017 \\
Potassium & 0.277 & 0.365 & -0.075 \\
Conductivity & $\mathbf{0 . 3 7 9}$ & 0.030 & 0.007 \\
Total dissolved solids & $\mathbf{0 . 3 0 6}$ & -0.028 & 0.092 \\
Ammonia & 0.074 & 0.227 & -0.291 \\
Nitrate & 0.145 & -0.293 & 0.027 \\
Nitrite & -0.015 & 0.074 & 0.420 \\
Phosphate & -0.075 & 0.120 & $\mathbf{0 . 5 6 9}$ \\
Total phosphorus & -0.078 & 0.080 & $\mathbf{0 . 6 0 5}$ \\
Total organic carbon & 0.063 & $\mathbf{0 . 5 4 3}$ & -0.047 \\
Chlorophyll & -0.062 & $\mathbf{0 . 5 0 5}$ & 0.011 \\
\% variation & $\mathbf{3 6 . 4}$ & $\mathbf{1 5 . 4}$ & $\mathbf{1 1 . 7}$ \\
\hline
\end{tabular}


Table 3. Types and number of farm ponds by geographicadministrative area arranged by west-east axis. Tipo y número de balsas de riego por área administrativa, ordenado según el eje oeste-este.

\begin{tabular}{lrrrrrrrrr}
\hline & HU & CA & SE & CO & JA & MA & GR & AL & Total \\
\hline EXC & 1 & 5 & 3 & 2 & 1 & 2 & 1 & 1 & 16 \\
RUN & 8 & 4 & 14 & 12 & 2 & 2 & 1 & 0 & 43 \\
CON & 0 & 0 & 0 & 0 & 3 & 5 & 7 & 21 & 36 \\
PLA & 3 & 0 & 0 & 0 & 6 & 3 & 2 & 11 & 25 \\
$\boldsymbol{n}$ & 12 & 9 & 17 & 14 & 12 & 12 & 11 & 31 & 120 \\
\hline
\end{tabular}

where field management is similar and, as a consequence, values are expected to be similar. Zooplankton, other biotic communities and physicochemical factors were completed at all sites.

All of the ponds visited are used in farming practice (irrigation or watering place), so water conductivity was not very high; however some of them presented values which suggested significant salinity (Table 1 ). The PCA analysis (Table 2) showed a first axis related to water salinity, suggesting that farm ponds are not suitable habitats for salinity tolerant zooplankton species, as wetlands, with higher salinity range, are. This property could be an important reason for the protection of these systems, because they would complement the lack of oligohaline habitats occurring in Andalusia due to the progressive salinization which historically occur in its natural systems (CMA, 2007).

Types of farm ponds by area and number falling into each category are shown in Table 3 . There is a significant tendency from west to east in relation to the type of farm pond. Natural (NAT) categories (RUN, EXC) are more common in the western areas, meanwhile artificial (ART) ones (PLA, $\mathrm{CON})$ are typical towards the east. Rainfall and types of farming seem to be less important (Fig. 2).

A total of 64 rotifer and 39 crustacean taxa were identified in farm ponds as a whole. This number is similar to others studies (Fahd et al., 2000; León et al., 2004, unpublished; Lougheed \& Chow-Fraser, 2002; Miracle et al., 1995; Serrano et al., 2005; Serrano \& Fahd, 2005). When comparing average values of cumulative richness (Table 4), it is observable that naturalized farm pond types (RUN, EXC) present a major number of taxa than artificial ones $(\mathrm{CON}$,
Table 4. Average values of species richness in 120 farm ponds related to taxROT (taxa of rotifers), taxCRU (taxa of crustaceans), taxTOT (taxa total), and DIV (Diversity $H^{\prime}$ ). Valores medios de riqueza de especies en 120 balsas de riego relativos a taxROT (taxones de rotíferos), taxCRU (taxones de crustáceos), taxTOT (taxones totales) y DIV (Diversidad $\mathrm{H}^{\prime}$ ).

\begin{tabular}{lcccc}
\hline & RUN & EXC & PLA & CON \\
\hline taxaROT & 4.65 & 3.73 & 2.13 & 3.51 \\
taxaCRU & 3.26 & 3.47 & 2.18 & 2.82 \\
taxaTOT & 8.00 & 7.20 & 4.27 & 2.37 \\
DIV $\left(\boldsymbol{H}^{\prime}\right)$ & 1.19 & 1.21 & 1.05 & 0.71 \\
\hline
\end{tabular}

PLA). To test this result, non-parametric analysis U-Mann Whitney was used. Significant differences $(p=0.05)$ appeared between artificial and natural farm ponds for taxROT (number of rotifera taxa), taxCRU (number of crustacean taxa) and div (diversity value), meanwhile these differences were no significant beneath any pair of the same type (NAT, natural types; ART, artificial types).

Correlations between pond size $\left(\right.$ area, $\mathrm{m}^{2}$ ) and zooplankton richness reflected differences among types of substrate. These correlations were high and positive when PLA and CON types $\left(\mathrm{r}^{2}=0.71,0.61,0.57, \mathrm{P}<0.01\right)$ were examined and no significant when RUN and EXC were compared. Therefore species-area hypothesis (Dodson, 1992; Fryer, 1985; MacArthur \& Wilson, 1963) was only checked for artificial farm ponds. Natural farm pond types did not corroborate this, as in other studies (Denoël \& Ficetola, 2008; Hoffman \& Dodson, 2005; Oertli et al., 2002; Williams et al., 2003).

Almost $80 \%$ of the taxa identified were present only in $10 \%$ of the farm ponds or less. Common species (present in more than $20 \%$ of farm ponds) were the copepods Acanthocyclops kieferi (Chappuis, 1925), A. robustus (G. O. Sars, 1893) and Copidodiaptomus numidicus (Gurney, 1909); Cladocera: Daphia magna (Straus, 1820), Simocephalus vetulus (Müller, 1776), Bosmina longirostris (Müller, 1776), Daphnia galeata (G. O. Sars, 1893) and Alonella nana (Braid, 1843) were present in almost $15 \%$ of farm ponds. Rotifers were represented by much more common species belonging to the genus $\mathrm{Bra}$ chionus, Keratella, Polyarthra, Lepadella and Hexarthra, which are typical taxa of water bodies through Iberian Peninsula (Alonso, 1996; de 
Table 5. Compared results on zooplankton biodiversity between wetlands (WET, $n=61$ ) and farm ponds (FPO, $n=120$ ). RO: number of rotifer taxa, CRU number of crustacean taxa, ROTexc and CRUexc: number of taxa of rotifers and crustaceans respectively, exclusive of each type of ecosystem. $R e$ sultados comparados de la biodiversidad del zooplancton entre humedales $(W E T, \mathrm{n}=61)$ y balsas de riego $(F P O, \mathrm{n}=120)$. RO: número de taxones de rotíferos, CRU número de taxones de crustáceos, ROTexc and CRUexc: número de taxones de rotiferos and crustáceos respectivamente, exclusivos de cada tipo de ecosistema.

\begin{tabular}{lccccc}
\hline & ROT & CRU & ROTexc & CRUexc & TOT \\
\hline WET & 54 & 60 & 26 & 38 & $\mathbf{1 1 4}$ \\
FPO & 62 & 41 & 36 & 17 & $\mathbf{1 0 3}$ \\
\hline
\end{tabular}

Manuel Barrabín, 2000). Of the farm ponds, only 7 of them contained no zooplankton taxa. All of them were ART (CON, PLA) type.

\section{Comparison with wetlands}

Results from the farm pond study were compared with other contemporary surveys carried out in Andalusia by EGMASA (Junta de Andalucía) over 61 natural wetlands protected by regional regulations (see figure 2 to location). A total of 114 taxa (54 rotifers, 60 crustaceans) were identified in this sampling, meanwhile 103 taxa were found in farm ponds. The comparison of results about the different zooplankton communities are presented in Table 5.

More than $50 \%$ of taxa were identified only in one of the wetland types (exclusive taxa). There were species exclusively found in farm ponds meanwhile others appeared only in wetlands. This result is unexpected because many of these water bodies are relatively close together (Fig. 2), so common species were expected to be higher. Much of the exclusive taxa identified in wetlands are species with tolerance to salinity: Moina salina (Daday, 1888), Alona salina (Alonso, 1995), Artemia sp., Arctodiaptomus salinus (Daday, 1885), Epiphanes sp. In contrast, species like Macrothrix hirsuticornis (Norman \& Brady, 1867), M. laticornis (Jurine, 1820), Chydorus sphaericus (Müller, 1776), Ceriodaphnia quadrangula (Müller, 1885), Dunhevedia crassa (King, 1853), typical from ponds with low salinity (Alonso, 1998) were found exclusively in the farm ponds.

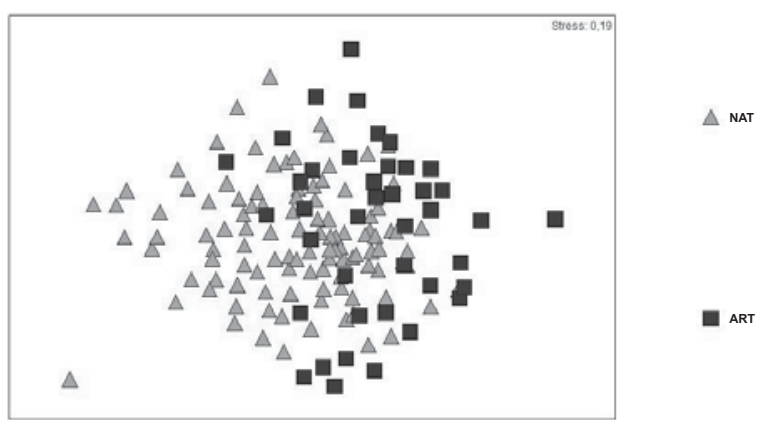

Figure 3. MDS analysis showing a softly clustering tendency towards type of ponds. NAT (naturalized) includes WET (wetlands), RUN (runoff farm ponds), EXC (excavated farm ponds); ART (artificial) includes PLA (farm ponds lined with plastic) and CON (farm ponds made of concrete bottom). MDS mostrando una ligera agrupación relativa al tipo de balsa. NAT (naturalizadas) incluye humedales (WET), balsas de escorrentía (RUN) y balsas excavadas con sustrato natural (EXC); ART (artificiales) incluye balsas de polietileno (PLA) y balsas de hormigón (CON).

MDS analysis of zooplankton richness within the whole water bodies, grouping them by NAT (RUN, EXC, including WET, wetlands) and ART (PLA, CON), indicates a clustering tendency that separates the ponds with artificial substrate from the ones with natural substrate (Fig. 3). The ANOSIM test did not reveal any significant difference in zooplankton composition between groups even among geographic areas (see Fig. 2 to location).

ANOVA one-way analysis showed no differences $(p>0.05)$ when taxTOT (total taxa of zooplankton), or diversity value (div) between WET, RUN and EXC were examined. Moreover, TStudent reaffirmed similarities in species richness and/or diversity between any NAT type (RUN, EXC or WET) and differences among any NAT type and any ART type (CON, PLA), (Table 6).

Table 6. $p$-values from T-Student analyses between types of farm ponds and wetlands for species richness and/or diversity. p-valores del T-Student entre tipos de balsas de riego y humedales para la riqueza de especies y/o la diversidad.

\begin{tabular}{lccccc}
\hline & WET & RUN & EXC & PLA & CON \\
\hline WET & & $\mathbf{. 3 5 1}$ & $\mathbf{. 5 3 0}$ & .045 & .000 \\
RUN & & & $\mathbf{. 5 4 3}$ & .002 & .000 \\
EXC & & & & .058 & .002 \\
PLA & & & & & $\mathbf{. 3 5 5}$ \\
CON & & & & & \\
\hline
\end{tabular}




\section{DISCUSSION}

Although the number of protected water bodies has increased in the last few years in Spain, it seems necessary to develop an environmental policy over wetlands, mainly over ponds and other small water systems. Ecological studies including: seasonal pasture wetlands (Robson \& Clay, 2005), irrigation and artificial pools (Lacomba \& Sancho, 2008), gravel or clay extraction pools, fish production ponds, duck farming reservoirs (Oertli et al., 2002), ditches (Williams et al., 2003), farm ponds (Céréghino et al., 2008), and highway storm-water detention ponds (Scher et al., 2004) have appeared in the present century as a response to this concern. Tilman et al. (2001) expected that $10^{9}$ ha of natural ecosystems will be converted to agriculture by 2050 . For this reason, it is necessary to maintain investigations on farming landscapes to assess the biodiversity of these ecosystems and to achieve the necessary results to improve environmentally friendly management of these specific areas.

Our results suggest that farm ponds in Andalusia, an area with a long history of agriculture, show a relatively high species richness of zooplankton at regional scale, therefore it is expected to be high in other groups of aquatic organisms relatively (results in progress).

Farm ponds in Andalusia seems to increase the availability of oligohaline habitats for zooplankton species, and also for other groups, which is crucial for conservation purposes due to the historic loss and degradation of these habitats. Farm ponds have low salinity due to their use for irrigation and other farming uses. Zooplankton community composition of farm ponds is different when compared to that of natural wetlands over the same area at the same time. Some saline tolerant taxa appeared only in wetlands, while many freshwater taxa were identified just in farm ponds. In natural wetlands, low salinity taxa have been found over sandy substrate in Doñana, the only complex of lagoons with low salinity remains in lowlands of Andalusia (Arechederra et al., 2006). Therefore, farm ponds seem to be able to contribute keeping and expanding their distribution area.
This study shows that natural farm ponds are richer in zooplankton species than artificial ones, as Scher et al. (2004) detected in their study. Statistical analyses over zooplankton richness revealed significant differences between some of artificial substrates and some of natural ones, meanwhile these differences were no significant beneath any pair of the same type (neither ART types, nor NAT types). Values of species richness were therefore higher in natural types. Moreover, statistical analyses showed no differences in zooplankton species richness and diversity between natural farm ponds and wetlands, but differences were significant when compared to artificial farm ponds. In agreement with Boavida (1999), these results support the idea that substrate is one of the most important factors to consider for wetland characterization. Natural substrate gives rise to the implementation of submerged plants, and therefore to the appearance of more habitats, so more species can colonize it. Artificial substrates (plastic, concrete), make it difficult for plants to take root and, furthermore, such ponds are frequently drained, as detected in the farmers interviews. As such, the development of habitat structural complexity is more complicated. The results demonstrating the absence of species in 7 artificial farm ponds could be due to the subterranean origin of water or maybe to the extended use of biocides in that area (south west of Andalusia). Further research into the colonisation rates of this pond type, with and without the use of biocides, needs to be undertaken.

Relationship between area and species richness was only proved for artificial ponds. Correlations were not significant for natural types. This matches up with other similar studies, suggesting that size is not the main factor when designing management policies to preserve biodiversity in aquatic systems at least for smallsized organisms. There are an increasing number of studies that reveal the importance of small water bodies as 'pockets' of biodiversity, in contrast to other larger systems.

In conclusion, farm ponds should be taken into account for strategies of biodiversity conservation in Andalusia. Therefore, the creation 
of new ponds with natural substrate and the promotion of environmentally friendly management practices is very important to increase biodiversity. We hope these results will encourage the Andalusia government to improve the future management of natural ponds in the agricultural landscape.

\section{ACKNOWLEDGEMENTS}

We are grateful to Agencia Andaluza Del Agua, EGMASA and Consejería de Medio Ambiente for funding and supporting this study. Thanks to María Gabriela Cano and María José Fernández for their help without, of course, forgetting to all the pond owners for their patience and help in all we needed. Finally, thanks to Sergio Segura, and María Fernández-García for their comments and corrections over the text.

\section{REFERENCES}

ALONSO, M. 1987. Ejemplos de vicarianza en comunidades de crustáceos de lagunas esteparias. Limnetica, 3: 81-89.

ALONSO, M. 1996. Crustacea, Branchiopoda. Fauna Ibérica, vol. 7. M. A. Ramos Museo Nacional de Ciencias Naturales, CSIC, (ed.) Madrid, 486 pp.

ALONSO, M. 1998. Las Lagunas de la España Peninsular. Limnetica 15: 1-176.

ANTÓN-PARDO, M., J. RUEDA, A. VIZCAÍNO \& X. ARMENGOL, 2008. Characterization of the zooplankton community of three peridunars ponds with different hydroperiod in L'Albufera Natural Park (Valencia, Spain). Abstract book from the third European Network Pond Workshop, Valencia, España: 62-63.

ARECHEDERRA, A., D. LEÓN, F. FAHD, J. TOJA \& L. SERRANO, 2006. The microcrustaceans and rotifers of Doñana. In Doñana: Water and Biosphere. F. García-Novo \& C. Martín-Cabrera (eds.): 342-343. Confederación Hidrográfica del Guadalquivir. Ministerio de Medio Ambiente.

BOAVIDA, M. J. 1999. Wetlands: most relevant structural and functional aspects. Limnetica, 17: 57-63.

CÉRÉGHINO, R., J. BIGGS, B. OERTLI \& S. DECLERCK, 2008. The ecology of European ponds: defining the characteristics of a neglected freshwater habitat. Hydrobiologia, 597: 1-6.

CÉRÉGHINO, R., A. RUGGIERO, P. MARTY \& S. ANGÉLIBERT, 2008. Biodiversity and distribution patterns of freshwater invertebrates in farm ponds of a south-western French agricultural landscape. Hydrobiologia, 597: 43-51.

CONSEJERÍA DE MEDIO AMBIENTE. JUNTA DE ANDALUCÍA, 2007. Comparación de la distribución de los usos del suelo en Andalucía de 1956 con la actual. Conferencia Internacional sobre Incendios Forestales, Sevilla, España. 87-90.

DAVIES, B. R., J. BIGGS, P. J. WILLIAMS, J. T. LEE \& S. THOMPSON, 2008. A comparison of the catchment sizes of rivers, streams, ponds, ditches and lakes: implications for protecting aquatic biodiversity in an agricultural landscape. Hydrobiologia, 597: 7-17.

DE MANUEL BARRABÍN, J. 2000. The rotifers of Spanish reservoirs: ecological, systematical and zoogeographical remarks. Limnetica, 19: 91-167.

DENOËL, M. \& G. F. FICETOLA, 2008. Conservation of new guilds in an agricultural landscape of Belgium: the importance of aquatic and terrestrial habitats. Aquatic Conserv: Mar. Fresh. Ecosyst., 18: 714-728.

DODSON, S. 1992. Predicting crustacean zooplankton species richness. Limnology and Oceanography, 37(4): 848-856.

DODSON, S., S. ARNOTT, \& K. COTTINGHAM, 2000. The relationship in lake communities between primary productivity and species richness. Ecology, 81(10): 2662-2679.

FAHD, K., L. SERRANO, \& J. TOJA, 2000. Crustacean and rotifer composition of temporary ponds in the Doñana National Park (SW Spain) during floods. Hydrobiologia, 436: 41-49.

FRYER, G. 1985. Crustacean diversity in relation to the size of water bodies: some facts and problems. Water Biology, 15: 347-361.

FUREST, A. \& J. TOJA, 1987. Tipificación de lagunas andaluzas según sus comunidades de crustáceos. Oxyura, IV: 89-100.

HOFFMAN, M. \& S. DODSON, 2005. Land use, primary productivity, and lake area as descriptors of zooplankton diversity. Ecology, 86(1): 255-261.

LACOMBA, I. \& V. SANCHO, 2008. Advances on the LIFE-Nature Project "Restoration of priority habitats for amphibians". Abstract book from the third European Network Pond Workshop. Valencia, España. 51. 
LEIBOLD, M. A. 1999. Biodiversity and nutrient enrichment in pond plankton communities. Evol. Ecol. Res., 1: 73-95.

LEÓN, D., L. SERRANO \& J. TOJA, 2004. Zooplancton en las lagunas del Parque Nacional de Doñana: Revisión bibliográfica y nuevas citas. $L i$ bro de Resúmenes del XII Congreso de la Asociación Española de Limnología, IV Congreso Ibérico de Limnología. Oporto, Portugal: 12.

LOUGHEED, V. \& P. CHOW-FRASER, 2002. Development and use of a zooplankton index of wetland quality in the Laurentian Great Lakes basin. Ecological Applications, 12(2): 474-486.

MacARTHUR, R. \& E. O. WILSON, 1963. An equilibrium theory of insular zoogeography. Evolution, 17: 373-387.

MARÍN CABRERA, C. \& F. GARCÍA NOVO, 2005. Doñana. Agua y Biosfera. Doñana 2005, Confederación Hidrográfica del Guadalquivir, Ministerio de Medio Ambiente. Madrid. 365 pp.

MIRACLE, M. R. 1982. Biogeography of the freshwater zooplanktonic communities of Spain. Journal of Biogeography, 9: 455-467.

MIRACLE, M. R., M. T. ALFONSO, E. VICENTE $\&$ W. KOSTE, 1995. Rotifers of spring pools in the costal marshland of Albufera of Valencia Natural Park. Limnetica, 11: 39-47.

MITTELBACH, G., C. STEINER, S. SCHEINER, K. GROSS, H. REYNOLDS, R. WAIDE, M. WILING, S. DODSON \& L. GOUGH, 2001. What is the observed relationship between species richness and productivity? Ecology, 82(9): 2381-2396.

OERTLI, B., D. AUDERSET, E. CASTELLA, R. JUGE, D. CAMBIEN \& J.B. LACHAVANNE, 2002. Does size matter? The relationship between pond are and biodiversity. Biological Conservation, 104: 59-70.

OERTLI, B., J. BIGGS, R. CÉRÉGHINO, P. GRILLAS, P. JOLY \& J.B. LACHAVANNE, 2005. Con- servation and monitoring of pond biodiversity: introduction. Aquatic Conserv: Mar. Fresh. Ecosyst., 15: 535-540.

ROBSON, B. \& C. CLAY, 2005. Local and regional macroinvertebrate diversity in the wetlands of a cleared agricultural landscape in south-western Victoria, Australia. Aquatic Conserv: Mar Fresh. Ecosyst., 15: 403-414.

SCHER, O., P. CHAVAREN, M. DESPRAUX \& A. THIÉRY, 2004. Highway stormwater detention ponds as biodiversity islands? Archive des Sciences, 57: 121-130.

SERRANO, L. \& K. FAHD, 2005. Zooplankton communities across a hydroperiod gradient of temporary ponds in the Doñana National Park (SW Spain). Wetlands, 25: 101-111.

SERRANO, L., M. REINA, G. MARTÍN, E. REYES, A. ARECHEDERRA, D. LEÓN \& J. TOJA. 2006. The aquatic systems of Doñana (SW Spain): watersheds and frontiers. Limnetica, 25: 11-32.

TILMAN, D., J. FARGIONE, B. WOLFF, C. D'ANTONIO, A. DOBSON, R. HOWARTH, D. SCHINDLER, W. H. SCHLESINGER, D. SIMBERLOFF \& D. SWACKAMER, 2001. Forecasting agriculturally driven global environmental change. Science, 292: 281-284.

WILLIAMS, D. 1997. Temporary ponds and their invertebrate community. Aquatic Conserv.: Mar. Freshwat. Ecosystems, 7: 105-117.

WILLIAMS, P., M. WHITFIELD, J. BIGGS, S. BRAY, G. FOX, P. NICOLET \& D. SEAR, 2004. Comparative biodiversity of rivers, streams, ditches and ponds in an agricultural landscape in Southern England. Biological Conservation, 115: 329-341.

WILLIAMS, P., M. WHITFIELD \& J. BIGGS, 2008. How can make new ponds biodiverse? A case study monitored over 7 years. Hydrobiologia, 597: 137-148. 